\title{
Генерация терагерцового излучения токами фотонного увлечения в квантовых ямах a-Sn/Ge
}

\author{
В. Н. Трухин ${ }^{1}$, И. А. Мустафин ${ }^{1}$, F. V. Kusmartsev ${ }^{2,3}$, A. Kusmartseva ${ }^{2}$, Y. Liu ${ }^{3}$, B. Zhang ${ }^{3}$, Y. Luo ${ }^{3}$ \\ ${ }^{1}$ ФТИ им. А.Ф. Иоффе РАН, 19021, г.Санкт-Петербург, Политехническая, 26 \\ ${ }^{2}$ Department of Physics, Loughborough University, UK \\ ${ }^{3}$ Nano-fabrication laboratory, MTRC, China \\ тел.: +7 (812) 292-7936, факс:+7 (812) 297-1017, эл. почта: valembr@mail.ru
}

DOI 10.34077/RCSP2021-69

В настоящей работе представлены результаты экспериментального исследования фототоков в наноструктурах на основе квантовых ям $\alpha-\mathrm{Sn} / \mathrm{Ge}$ при их возбуждении фемтосекундными оптическими импульсами, как непосредственно контактным методом, так и регистрацией терагерцового излучения, индуцированного этими фототоками. Данная структура представляет интерес с точки зрения получения нового топологического материала [1]. Исследуемые образцы представляли собой нанометровые слои $\mathrm{Ge}$ и $\alpha$-Sn, синтезированные методом электронно-лучевого осаждения на поверхность подложки кремния с верхним слоем $\mathrm{SiO}_{2}$. В ходе экспериментальных исследований наноструктур контактным методом измерялся фототок, а посредством методов терагерцовой времяразрешенной спектроскопии регистрировалась волновая форма ТГц импульса, генерируемого при возбуждении образца сверхкороткими лазерными импульсами фемтосекундной длительности. По результатам исследований терагерцовой генерации в образцах на основе только пленок Ge и $\alpha$-Sn было показано, что механизм процесса генерации ТГц излучения в этих образцах обусловлен возбуждению токов амбиполярной диффузии, процессу схожему с генерацией в объёмном InAs. При исследовании образцов, содержащих одну или несколько квантовых ям $\alpha-\mathrm{Sn} / \mathrm{Ge}$ было обнаружено, что при изменении поляризации возбуждающего света от ТМ к ТЕ - амплитуда ТГц импульса изменяет свой знак и зависимость амплитуды ТГц импульса от угла поворота вектора поляризации имеет синусоидальный характер (рис.1).

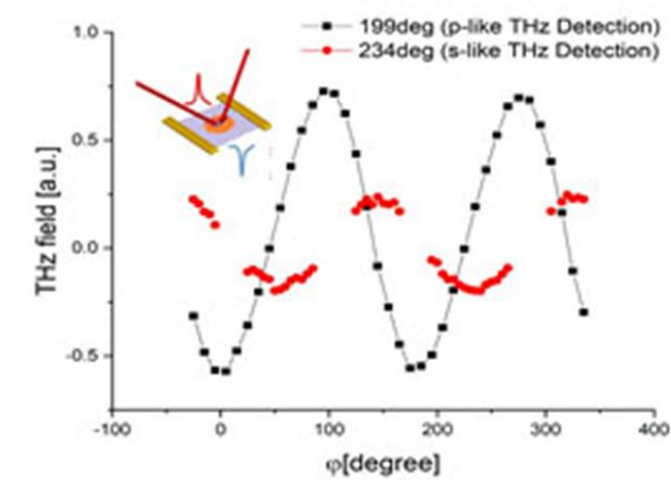

Рис. 1 . Зависимость амплитуды ТГц импульса (красным - ТЕ поляризация, чёрным - ТМ поляризация) от направления вектора поляризации возбуждающего света.
При смене направления распространения света наблюдается инверсия знака фототока и амплитуда ТГц импульса пропорциональна интенсивности возбуждающего света (рис.1). Наблюдаемые зависимости фототока от поляризации света, направления волнового вектора и интенсивности возбуждаемого света присущи току фотонного увлечения. Расчет тока увлечения на основе феноменологического подхода подтвердил соответствие рассчитанных зависимостей с экспериментальными данными. Природа процесса ТГц генерации в $\alpha-\mathrm{Sn} / \mathrm{Ge}$, по-видимому, обусловлена проявлением асимметрии в импульсном пространстве неравновесных электронов при межзонных переходах в наноструктуре, являющую собой новый класс топологических материалов.

Исследование выполнено при финансовой поддержке РФФИ и Лондонского Королевского Общества № 21-52-10015.

\section{Лumepamypa}

[1] N. P. Armitage et all // Rev. Mod. Phys.2018.V.90, P. 015001. 